УДК 621.35

DOI https://doi.org/10.32838/2663-5941/2020.2-1/33

Токайчук T.M.

Національний технічний університет «Харківський політехнічний інститут»

Сьомкіна О.В.

Національний технічний університет «Харківський політехнічний інститут»

Смирнова О.Л.

Національний технічний університет «Харківський політехнічний інститут»

\title{
Панчева Г.М.
}

Національний технічний університет «Харківський політехнічний інститут»

\section{Пилипенко О.I.}

Національний технічний університет «Харківський політехнічний інститут»

\section{ДОСЛІДЖЕННЯ ДИНАМІКИ ФОРМУВАННЯ ОКСИДНИХ ПЛІВОК НА СПЛАВІ ТІ6АL4V У ЕЛЕКТРОЛІТАХ НА ОСНОВІ ЕТИЛЕНГЛІКОЛЮ}

Наведені результати дослідження утворення оксидних плівок на сплаві Ti6Al4V у електролітах, щзо складаються з етиленгліколю, води (5 об. \%) і $\mathrm{NH}_{4} \mathrm{~F}$. Показано, щз за с $\left(\mathrm{NH}_{4} \mathrm{~F}\right)=0,5-2,0$ г $\pi^{-1}$ формувальні залежності, що відображають динаміку утворення оксидних плівок на металі при електрохімічному окисленні, є лінійними залежностями напруги на коміриі від часу електролізу. Отримані дані вказують на те, що анодне окислення сплаву за цих умов приводить до утворення оксидних плівок діелектричного типу, для яких максимальна товщина визначається величиною напруги. Забарвлення отриманих плівок не залишається постійним і не відповідає кольору плівок, отриманих у разі оксидування сплаву в електролітах, щзо не містять іонів-активаторів. Кут нахилу формувальних залежностей збільшується зі зростанням густини анодного струму, що узгоджується з пропориійним збільшенням швидкості окислення металу під час підвищення заданого значення густини струму ја. У електролітах, що містять

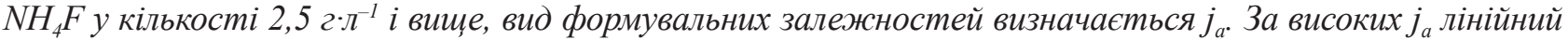
хід залежностей вказує на те, що швидкість утворення плівки перевищуе швидкість ії хімічного роз-

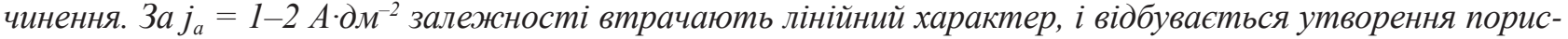
тих оксидних плівок. Отримані дані дозволяють зробити висновок про можливість формування плівок бар'єрного та пористого типів шляхом зміни параметрів електролізу при електрохімічному окисленні сплаву Ti6Al4V у розчинах на основі етиленгліколю. Вони є передумовою для розробки технологічних основ отримання оксидних плівок з функиіональними властивостями з можливістю використання як біоінертних і біосумісних покриттів основи для отримання каталізаторів, корозійностійких покриттів.

Ключові слова: анодна поляризація, оксидна плівка, електрохімічне осадження, поляризаційна залежність, діоксид титану.

Постановка проблеми. Хімічна стійкість титану зумовлена наявністю тонкою (5-6 нм) оксидною плівкою, яка утворюється під час контакту металу з кисневмісними реагентами. Шар 3 непровідного $\mathrm{TiO}_{2}$ майже не має пор і сприяє глибокій пасивації титану. Оксидні плівки не тільки пасивують титан. Титан використовується для виготовлення зубних протезів, елементів суглобів, ниток, сіток, пластин, виробів для щелепно-лицевої хірургії [1]. Біоінертність плівки зумовлює відсутність алергічних реакцій і швидке формування кістково-м'язової тканини, яка не змінюється протягом життя пацієнта [2].

Аналіз останніх досліджень i публікацій. Недоліком титанових сплавів $є$ зниження хімічної стійкості за збільшення легуючих елементів. Поверзнева корозія імплантатів приводить до викришування часток металу і утворення сполук $\mathrm{V}$ i Al з протіканням запальних процесів [3]. Для більшої надійності поверхню титану модифікують шляхом формування керамічних, фосфатних або оксидних покриттів [4-7]. Оксидні плівки 
отримують переважно електрохімічним окисленням (ЕО), оскільки метод дозволяє отримувати однорідні плівки на складних виробах. Структура і товщина плівки визначається робочим електролітом [8; 9]. Якщо він не взаємодіє з плівкою, утворюється бар'єрна плівка 3 діелектричними властивостями. Введення до електроліту активаторів сприяє утворенню пористих плівок неоднорідної структури. У змішаних електролітах можна одержати впорядковані пористі плівки 3 порами визначеного діаметру. 3 огляду на це мета статті полягає у дослідженні процесів ЕО сплаву Ti6Al4V у етиленгліколь-водних розчинах.

Виклад основного матеріалу дослідження. Методика. Для дослідження використовували зразки сплаву, виготовлені з прутка діаметром 4 мм. Зразки шліфували пелюстковим кругом, промивали бензином, знежирювали водною суспензією карбонату натрію, травили у суміші $\mathrm{HNO}_{3}: \mathrm{HF}$ (3:1) та промивали водою. Електроліз проводили у гальваностатичному режимі, використовуючи джерело живлення Б5-49 до досягнення напруги на комірці 100 В. Зміну напруги на комірці відстежували мультиметром Keithley-2000. Як допоміжний електрод використовували свинець. Для приготування розчинів використовували хімічні реактиви кваліфікації «ч.д.а.».

Результати досліджень. Найбільш інформативним для дослідження процесів ЕО $\epsilon$ аналіз формувальних залежностей типу $U-f(\tau)$, які одержують шляхом реєстрації зміни напруги на комірці у часі під час гальваностатичного електролізу. $U-f(\tau)$ залежності дозволяють не тільки відстежити динаміку росту плівки, але й зробити висновки щодо структури одержаного шару. Одержані експериментальні дані вказують, що

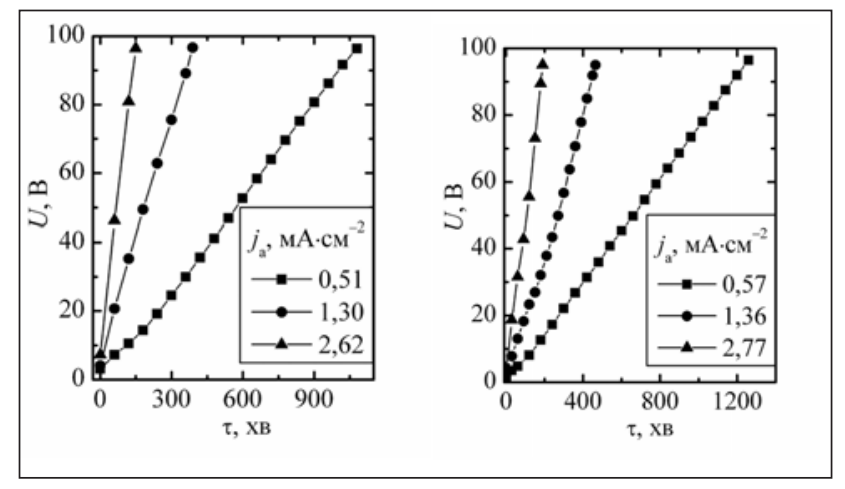

a)

б)

Рис. 1. Формувальні залежності, одержані при електрохімічному оксидуванні титанового сплаву Ti6Al4V у розчині складу 95 об. \% $\left(\mathrm{CH}_{2}\right)_{2}(\mathrm{OH})_{2}+$ 5 об. \% $\mathrm{H}_{2} \mathrm{O} . c\left(\mathrm{NH}_{4} \mathrm{~F}\right), \Gamma^{\bullet} \mathrm{J}^{-1}: a-1,5 ; \sigma-2,0$ визначальний вплив на утворення плівки має склад електроліту, а саме - вміст у ньому фториду амонію. Формувальні залежності, одержані при $c\left(\mathrm{NH}_{4} \mathrm{~F}\right)=0,5-2 \Gamma^{\cdot} \pi^{-1}$, мають лінійній хід, що свідчить про формування оксидних плівок з незначною пористістю (рис. 1, $a$ ).

Кут нахилу залежностей у цьому діапазоні $c\left(\mathrm{NH}_{4} \mathrm{~F}\right)$ зменшується 3 підвищення густини струму (рис. 1, б), що пояснюється збільшенням швидкості електрохімічного окислення сплаву у гальваностатичному режимі за 100\%-го виходу за струму окислення титану.

Підвищення $c\left(\mathrm{NH}_{4} \mathrm{~F}\right)>2,5 \quad \Gamma^{\cdot} \pi^{-1}$ зумовлює зміну ходу формувальних залежностей (рис. 2), які втрачають лінійність і демонструють складну зміну напруги на комірці. Цей ефект більш чітко проявляється під час електролізу за низьких $j_{\mathrm{a}}$ (рис. 2, a). При ЕО за $j_{\mathrm{a}}>0,6 \mathrm{MA} \cdot \mathrm{cm}^{-2}$ ефект зникає, що вказує на більшу швидкість електрохімічного утворення плівки, порівняно з швидкістю ії хімічного розчинення у електроліті. Вид формувальних залежностей, одержаних при $j_{\mathrm{a}}>1,39 \mathrm{MA} \cdot \mathrm{cm}^{-2}$ (рис. 2, б), зумовлюється вмістом фториду амонію у електроліті.

Формувальні залежності, одержані за цих умов, характеризуються наявністю декількох ділянок, що відповідають утворенню оксидного шару бар'єрного типу, появі пор і ЕО з поступовим наростанням пористої частини оксиду. 3 підвищенням концентрації іонів фтору швидкість хімічного розчинення плівки зростає, що видно 3 пологого ходу одержаних кривих.

Отримані результати пояснюються, якщо прийняти до уваги положення теорії утворення оксидних шарів бар'єрного типу. За незначного вмісту іонів $\mathrm{F}^{-}$швидкість формування плівки

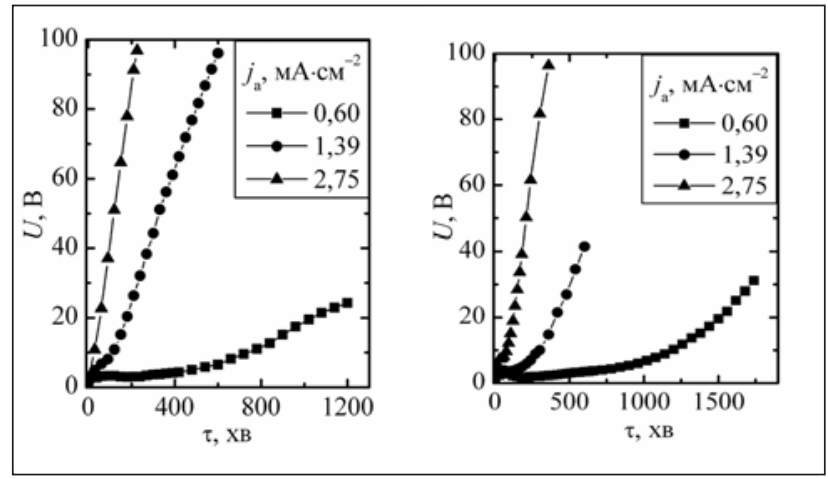

a)

б)

Рис. 2. Формувальні залежності, одержані під час електрохімічного оксидування титанового сплаву Ti6A14V у розчині складу 95 об. \% $\left(\mathrm{CH}_{2}\right)_{2}(\mathrm{OH})_{2}+$ 5 об. \% $\mathrm{H}_{2} \mathrm{O} . c\left(\mathrm{NH}_{4} \mathrm{~F}\right), \Gamma^{\cdot} \pi^{-1}: a-5 ; \sigma-10$ 
значно перевищує швидкість іiі хімічного розчинення у електроліті. Наявної кількості фторидіонів недостатньо для забезпечення активації поверхні сплаву. Це приводить до лінійного росту напруги на комірці (рис. $1, a$ ), зумовленого омічним опором оксидного шару 3 діоксиду титану. Швидкість утворення такого шару зростає зі збільшенням кількості окисленого металу, що в умовах постійної швидкості хімічного розчинення викликає прискорене досягнення заданої напруги (рис. 1, б). Такий вплив проявляється навіть у розчинах, що містять $10 \Gamma^{\circ} \pi^{-1} \mathrm{NH}_{4} \mathrm{~F}$ (рис. 2, $a$ ). За низьких значень густини струму формування плівки відбувається в умовах більшого впливу хімічної взаємодії з електролітом і зумовлює складний процес залежностей. Зміна умов електролізу дозволяє проводити формування як малопористих плівок діелектричного типу, так і двошарових плівок з бар'єрною і пористою частинами.
Висновки. Досліджена динаміка електрохімічного окислення титанового сплаву Ti6Al4V у етиленгліколь-водних розчинах 3 додаванням $\mathrm{NH}_{4} \mathrm{~F}$. Формувальні залежності дозволили встановити, що залежно від умов проведення процесу можливе утворення плівок різного типу. Проведення окислення за $c\left(\mathrm{NH}_{4} \mathrm{~F}\right)=0,5-2,0 \Gamma^{\cdot} \pi^{-1}$ зумовлює лінійний хід, що вказує на утворення малопористих плівок діелектричного типу. Під час підвищення $c\left(\mathrm{NH}_{4} \mathrm{~F}\right)>2,5 \Gamma^{\circ} \pi^{-1}$ визначальний вплив на структуру оксидної плівки має густина струму. За $j_{\mathrm{a}}=0,6 \mathrm{мA} \cdot \mathrm{cm}^{-2}$ спостерігається лінійний хід залежностей. При $j_{\mathrm{a}}>1,39 \mathrm{мA} \cdot \mathrm{cm}^{-2}$ утворюються двошарові оксидні плівки з бар'єрною і пористою частинами. Одержані результати встановлюють зв'язок між умовами проведення окислення і структурою плівки, що $є$ передумовою для розробки технології електрохімічного оксидування сплаву Ti6Al4V.

\section{Список літератури:}

1. Khorasani A.M., Goldberg M., Doeven E.H. [et al.]. Titanium in biomedical applications - properties and fabrication: a review. J. Biomater. Tiss. Engin. 2015. Vol. 5. P. 593-619.

2. Li Y., Yang C., Zhao H. [et al.]. New developments of Ti-based alloys for biomedical applications. Mater. 2014. Vol. 7. P. $1709-1800$.

3. Adya N., Alam M., Ravindranath T. [et al.]. Corrosion in titanium dental implants: literature review. J. Indian Prosthodont. Soc. 2005. Vol. 5. P. 126-131.

4. John A.A., Jaganathan S.K., Supriyanto E. [et al.]. Surface modification of titanium and its alloys for the enhancement of osseointegration in orthopaedics. Curr. Sci. 2016. Vol. 111. P. 1003-1015.

5. Diefenbeck M., Mückley T., Schrader C. [et al.]. The effect of plasma chemical oxidation of titanium alloy on bone-implant contact in rats. Biomaterials. 2011. Vol. 32. P. 8041-8047.

6. Park E.J., Song Y.H., Hwang M.J. [et al.]. Surface characterization and osteoconductivity evaluation of micro/nano surface formed on titanium using anodic oxidation combined with $\mathrm{H}_{2} \mathrm{O}_{2}$ etching and hydrothermal treatment. J. Nanosci. Nanotechnol. 2015. Vol. 15. P. 6133-6136.

7. Lubas M., Sitarz M., Jasinski J.J. [et al.]. Fabrication and characterization of oxygen-diffused titanium using spectroscopy method. Spectrochim. Acta A Mol. Biomol. Spectrosc. 2014. Vol. 133. P. 883-886.

8. Pilipenko A., Pancheva H., Deineka V. [et al.]. Formation of oxide fuels on VT6 alloy in the conditions of anodial polarization in solutions $\mathrm{H}_{2} \mathrm{SO}_{4}$. EEJET. 2018, Vol. 3. P. 33-38.

9. Ivashchenko M., Smirnova O., Kyselova S. [et al.]. Establishing the patterns in the formation of films on the alloy Ti6A14V in carbonic acid solutions. EEJET. 2018. Vol. 5. P. 21-26.

\section{Tokaichuk T.M., Semkina O.V., Smirnova O.L., Pancheva H.M., Pilipenko O.I. STUDY OF THE DYNAMICS OF FORMATION OXIDE FILMS ON Ti6AI4V ALLOY IN ETHYLENE GLYCOL BASED ELECTROLYTES}

The data obtained during the studies of the peculiarities of the formation of oxide films on the Ti6Al4V alloy in the electrolytes consisting of ethylene glycol, a small quantity of water (5 vol. \%) and ammonia fluoride have been given. It was shown that the forming dependences that reflect the formation dynamics of oxide films on the alloy during the electrochemical oxidation in the electrolytes with ammonia fluorides concentrations varying in the range of 0.5 to $2 \mathrm{~g} \cdot \mathrm{l}^{-1}$ represent a linear dependence of the cell voltage on the electrolysis time. The obtained data are indicative of that the anode oxidation in the alloys under these conditions results in the formation of the oxide films of a dielectric type and in this case a maximum thickness is defined by the voltage value. The color of obtained films is not permanent and it is not corresponding to the color of the films obtained during the oxidation of alloy in the electrolytes that contain no activating ions. The slope angle of forming dependences is increased with an increase in the anode current density and it agrees with a proportional increase in the metal oxidation rate with an increase in the preset value of ja. For the electrolytes 
with the ammonia fluoride concentration of $2.5 \mathrm{~g} \cdot \mathrm{l}^{-1}$ and higher the type of forming dependences is defined by the used current density. At high current densities, a linear behavior of the dependences is indicative of that the film formation rate exceeds that of its chemical dissolution. At the current densities of 1 to $2 \mathrm{~A} \cdot \mathrm{dm}^{-2}$ the dependences lose their linear behavior and porous oxide films are formed. The obtained data allow us to draw a conclusion on the possibility of the formation of the films of barrier and porous types by way of a change in electrolysis parameters during the electrochemical oxidation of the Ti6Al4V alloy in ethylene glycol-based solutions. These serve as a prerequisite for the development of technological bases for the formation of oxide films with the functional properties that would allow them to be used as bioinert and biocompatible coatings and serve as a base for the formation of photocatalysts and corrosion-resistant coatings

Key words: anode polarization, electrochemical oxidation, oxide film, forming dependence. 